\title{
Application of Grey TOPSIS in Preference Ordering of Action Plans in Balanced Scorecard and Strategy Map
}

\author{
Mohammadreza SADEGHI ${ }^{1 *}$, Seyed Hossein RAZAVI ${ }^{1}$, \\ Narges SABERI ${ }^{2}$ \\ ${ }^{1}$ Industrial Management Department, Faculty of Management and Accounting \\ Allameh Tabatabaei University, Tehran, Iran \\ ${ }^{2}$ Department of Industrial Engineering, Islamic Azad University of Ghazvin, Iran \\ e-mail:m.r.sadeghi61@gmail.com,m.r.sadeghi@st.atu.ac.ir,sh.razavi@st.atu.ac.ir, \\ nasaberi@yahoo.com
}

Received: 3 2011; accepted: April 2012

\begin{abstract}
Strategy implementation" is an inseparable part of strategic management process. Transformation strategies to typical operations and daily functions of staff exert a significant role in organization success. Balanced scorecard (BSC) and strategy map help senior managers to perfectly implement and monitor the accomplishment of the strategies by transforming strategies into operational programs. Using BSC and strategy map, the strategies are translated into some action plans which help the achievement of organizational goals and strategies. Due to shortage of resources, usually all organization's action plans cannot be implemented completely; therefore, managers should make use of some tools for assigning and selecting more efective action plans. In this paper, a procedure is suggested on the basis of grey TOPSIS to determine the preference of action plans to better aid managers in selection of the most effective action plans in a group decision making process.
\end{abstract}

Key words: balanced scorecard, strategy map, TOPSIS, grey theory.

\section{Introduction}

Strategic management is defined as "Art and science of formulating, implementing, and evaluating cross-functional decisions that enable an organization to achieve its objectives" (David, 2009). Value for different stakeholders of an organization is created by formulating and defining vision, mission and strategies. Hence a major part of strategic management is strategy implementation whereas strategy statement, vision and mission are introduced to staff but the meaning and their roles in achieving the goals are not clear for them.

So organizations are faced with the challenge of strategy implementation, and managers are always seeking a method for conducting strategies and assessing their success in achieving the planned goals.

\footnotetext{
*Corresponding author.
} 
Many studies have revealed that $70 \%$ to $90 \%$ of different organizations are failed while performing strategy (Kaplan and Norton, 2007a). To successfully perform main strategies, identification and creation links between short term objectives and long term goals is important, as satisfying short term goals generally means successful strategy execution (Pearce and Robinson, 1997). Kaplan and Norton in 1990s proposed the concepts of BSC and strategy map in four different perspectives as a tool to translate mission and strategies into objectives and measures. In their point of view, strategy determines how the organization will create value for different stakeholders (Kaplan and Norton, 1996a). Their studies' results emphasize how the organizations obtain their competitive advantage by intangible assessments such as human capital, Information systems, qualified processes and brands. Kaplan and Norton have defined strategy map as a tool to describe how the value is created in the organization (Kaplan and Norton, 1993).

In strategy implementation, it's important to determine priority of action plans. Due to the shortage of resources, organization cannot perform all action plans, so the most important and effective ones should be selected. Different criteria for ordering and selection of the best action plans should be considered by Managers. In fact, ranking and selecting action plans is a multiple criteria decision making (MCDM) problem where managers' judgments about action plans are not generally precise, so it's usually described by verbal phrases. In this work, a procedure based on grey systems theory and TOPSIS is used to determine the preference of action plans according to managers' uncertain judgments.

Grey system indicates the framework of relationship between basic variable and other system's variables. Grey systems are chosen due to color of study. The term Grey is used to illustrate the incomplete information. Grey systems are described by grey numbers and sets. Generally, grey systems theory divides the system into three categories: white, black and grey, where white part is the demonstration of the clear messages and black section is the indication of completely unknown messages. Incomplete information or uncertain information shows the grey part of system. In other word, grey uncertainty comprises both known and unknown messages (Deng, 1989).

In this research, after determining strategies and action plans based on BSC and strategy map concepts, a procedure based on grey theory and TOPSIS is used for defining the preference of action plans. Grey systems theory has extensive application in MCDM problems of ambiguous and non deterministic situations. Zhang et al. (2005), Cao et al. (2006), Dong et al. (2006), Li et al. (2007) and Kuo et al. (2008) are some of the research which has indicated the application of grey theory in MCDM problems. There are also some researches that used this method to evaluate different organizations' strategies. Alizadeh et al. (2008) have used grey theory to propose a model for evaluating organization's vision. Kung and Wen (2007) have used this method to assess the relationship between corporation's aspects and financial performance.

In the following two parts, the basic concept of proposed method, that is, Strategy map and Grey theory have been reviewed. In the fourth part, the procedure of grey TOPSIS has been explained in a stepwise manner. In the last part, grey TOPSIS has been used in a numerical example. 


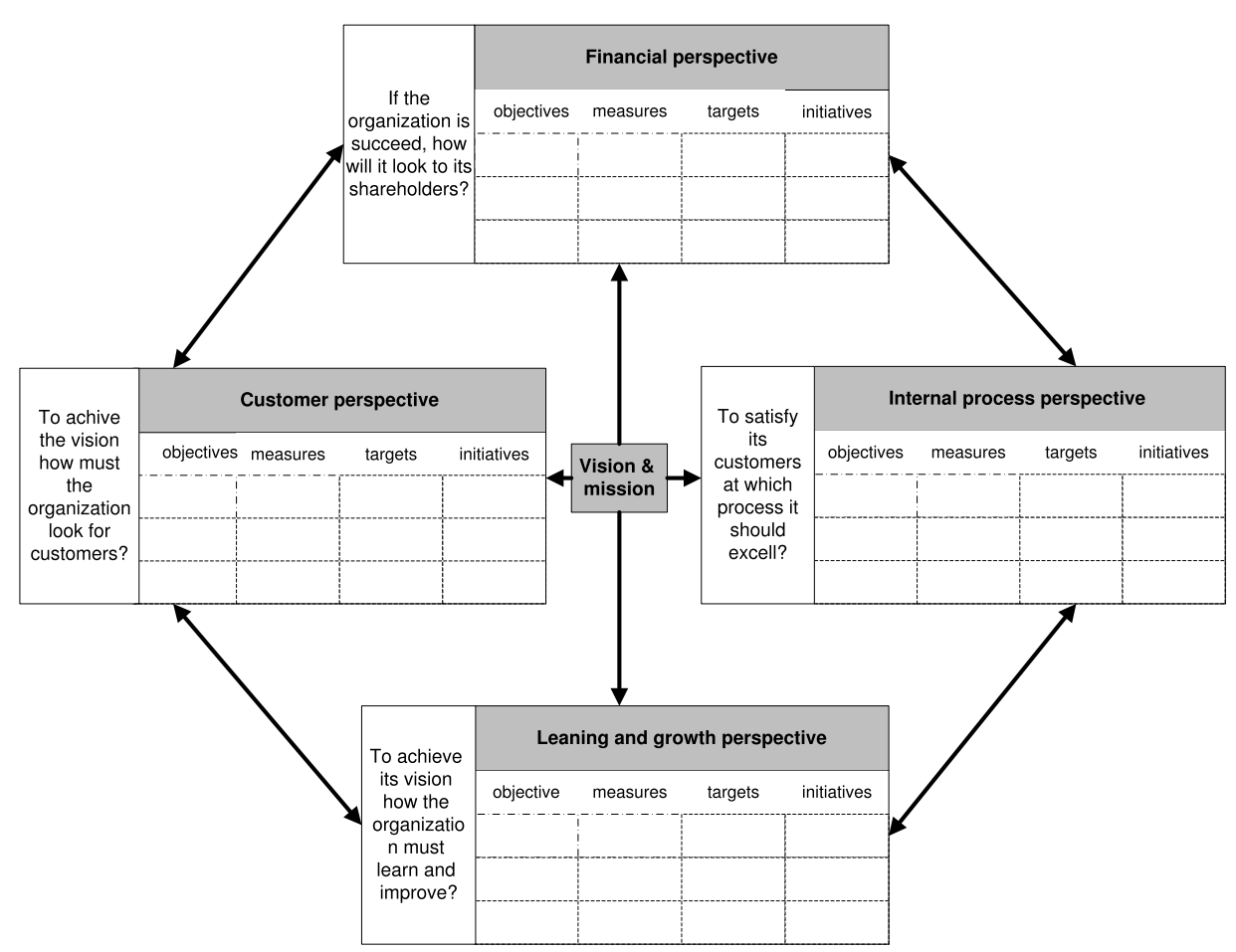

Fig. 1. The perspectives of BSC.

\section{BSC and Strategy Map}

The BSC, first proposed in 1990s, provides executives with a comprehensive framework that translate a company's strategic objectives into a coherent set of performance measures (Kaplan and Norton, 1993). Kaplan and Norton's suggestion about the importance of organization's intangible assets in creating value and obtaining competitive advantages caused a challenge in organization performance measurement systems which were merely based on financial measures. They argued that organizations should keep the financial measures to summarize activity results, but these measures must be supplemented by three groups of nonfinancial measures (Kaplan and Norton, 1993). So BSC was used as a performance evaluation measure in its early years of introduction. This tool has a significant position in strategic management literature and has been used as a popular tool for managers to acquire appropriate information in organization activities control. BSC concept has been widely adopted by manufacturing and service companies, nonprofit organizations, and government entities around the world since its introduction in 1992 (Kaplan and Norton, 2001a). BSC measures and monitors performance of organizations in 4 perspectives (Kaplan and Norton, 2008). These perspectives are shown in Fig. 1 (Kaplan and Norton, 1996a).

Each perspective has some measures and its targets that help the managers to control and monitor the organization performance. These perspectives are: 
Financial perspective. The financial perspective describes the tangible outcomes of strategy in traditional financial terms. Measures like ROI, shareholder value, profitability, revenue growth and cost per unit are the "lag indicators" or outcomes, which indicate whether the organization's strategy is succeeding or failing (Kaplan and Norton, 2004b). Companies increase financial performance through two basic approaches; revenue growth and productivity development. Link between the strategy and financial perspective prevent the conflict between long and short term goals (Kaplan and Norton, 2007a).

Customer perspective. The core of any business strategy is the customer-value proposition, which describes the unique mix of product, price, service, relationship and image which are offered by a company. It defines how the organization differentiates itself from competitors to attract, retain, and deepen relationships with targeted customers. The value proposition is crucial because it helps an organization to connect its internal processes to improved outcomes with its customers (Kaplan and Norton, 2001a). The main measures used in this perspective are: customer satisfaction, customer retention, customer acquisition, customer profitability, market share and account share (Kaplan and Norton, 1996b). It should be noticed that organizations do not need all of these measures or values whereas some organizations may consider different values and measures.

Internal process perspective. Once an organization has a clear picture of its customer and financial perspectives, the means which create the value proposition and productivity improvements for the financial objectives is determined. One or more operational activities should be carried out effectively and efficiently to achieve the customer perspective goals.

These processes should be defined in internal process perspective and also appropriate measures must be considered for improvement (Kaplan and Norton, 2001a). Internal processes of organization are divided into 4 groups: (1) operational process, (2) customer management process, (3) innovation process and (4) legal and social process (Kaplan and Norton, 2007a). Customer perspective's goals and presenting distinctively from the competitors are obtained by performing these processes.

Learning and growth perspective. The fourth BSC perspective, Learning \& Growth, is identification of the infrastructure that the organization must build to create long-term growth and improvement. The most critical factors for current and future success are recognized using the customer and internal business perspectives (Kaplan and Norton, 2007a). Organizational learning and growth come from three principal sources: people, systems, and organizational procedures. The financial, customer and internal business process objectives on BSC typically reveal large gaps between existing capabilities of people, systems, procedures and also required infrastructure to achieve targets for breakthrough performance (Kaplan and Norton, 2008).

Hence BSC is defined as the new organization performance evaluation system. Gradually this method was used as a tool to coordinate organizational resources and focus on strategy implementation (Kaplan and Norton, 2001b). While this method is used as strategy implementation tool, strategy map can be used as an operational program coordinator. Strategy map indicates causal relationships among available components of 4 


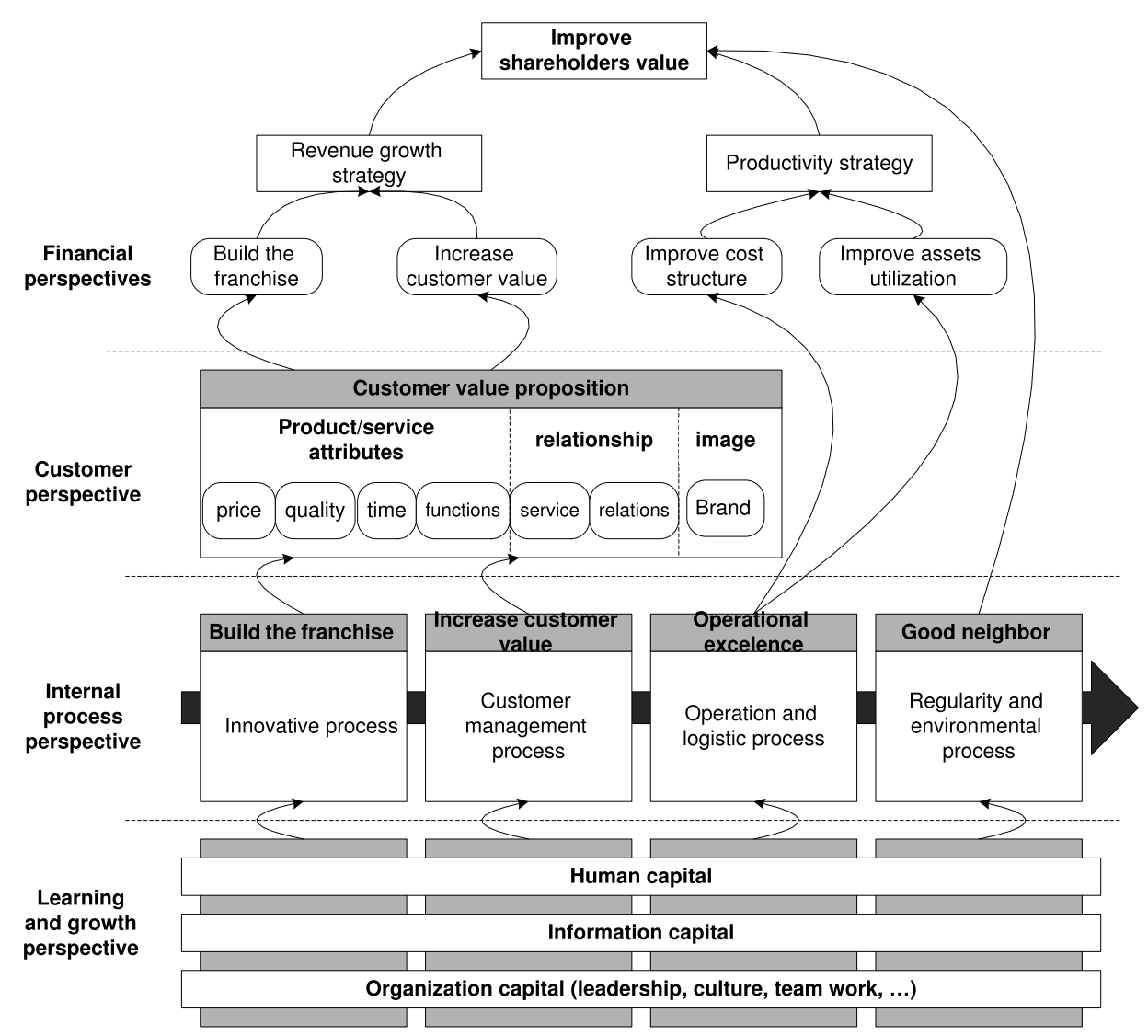

Fig. 2. The BSC strategy map.

necessary perspectives for strategy realization (Kaplan and Norton, 2007b). Strategy map is a communication tool used to tell a story of how value is created for the organization. It shows a logical and step-by-step connection between strategic objectives (shown as ovals on the map) in the form of cause-and-effect chain. Generally, improving performance in Learning \& Growth enables the organization to improve its Internal Process Objectives, which enables the organization to create desirable results in the Customer and Financial perspectives.

There are several different approaches to formulate strategy; despite these varieties, strategy map and BSC creates common method to describe strategies (Kaplan and Norton, 2007a). In fact, strategy map is applied as a complementary to BSC for implementing strategies. Figure 2 depicts the BSC strategy map.

The role of Strategy map and BSC in strategic management process is shown in Fig. 3 (Kaplan and Norton, 2007a). Vision and mission statements determine organization main goals and aims which help shareholders, customers and staffs to understand current and future situation of company. Strategy illustrates the path by which organization can achieve its main goals. Strategy map and BSC help organization to translate strategies into rou- 


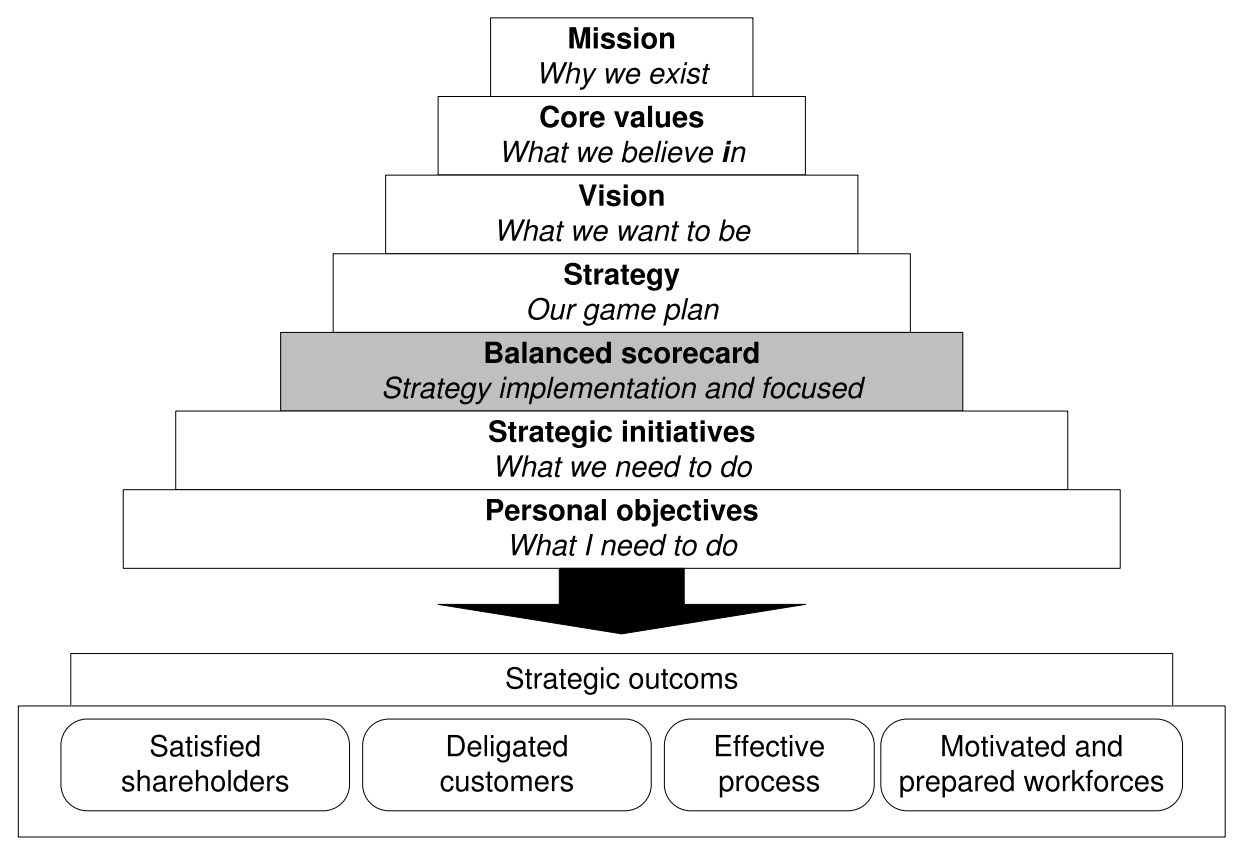

Fig. 3. Translating strategy into desired outcomes.

tine and daily operation for staffs (Kaplan and Norton, 2004a). For implementation of organization strategies, next steps should be followed:

1. Determination of causal relationship between components of each perspective of BSC for every strategy.

2. Indication of measures and goals that help to realize causal relationship.

3. Determination of action plans that lead to realized goals and measures.

\section{Grey Theory}

Grey theory, which was proposed by Deng in 1982, is one of the new mathematical theories born out of the concept of the grey set. It is an effective method used to solve uncertainty problems with discrete data and incomplete information. The theory includes five major parts: grey prediction, grey relational analysis (GRA), grey decision, grey programming and grey control (Deng, 1989). Some basic definitions of the grey system, grey set and grey number in grey theory are given here:

Definition 1. A grey system is defined as a system containing uncertain information presented by a grey number and grey variables. The concept of a grey system is shown in Fig. 4. 


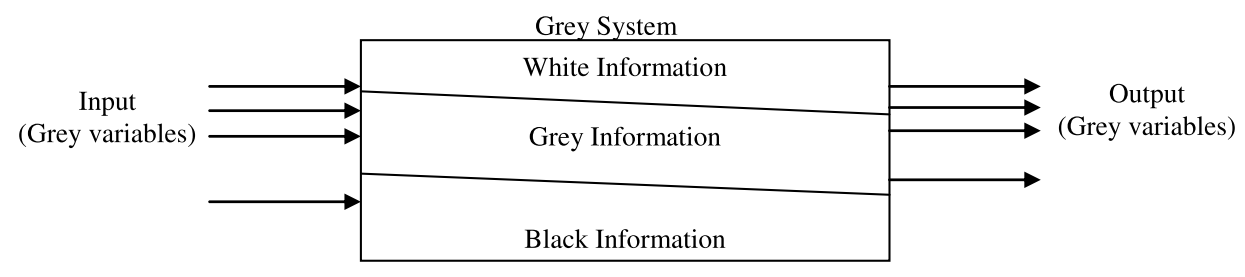

Fig. 4. Concept of grey system.

Definition 2. Let $X$ is the universal set. Then a grey set $G$ of $X$ is defined by its two mappings $\bar{\mu}_{G}(x)$ and $\underline{\mu}_{G}(x)$.

$$
\left\{\begin{array}{l}
\bar{\mu}_{G}(x): x \rightarrow[0,1], \\
\underline{\mu}_{G}(x): x \rightarrow[0,1] .
\end{array}\right.
$$

$\bar{\mu}_{G}(x) \geqslant \underline{\mu}_{G}(x), x \in X, X=R, \bar{\mu}_{G}(x)$ and $\underline{\mu}_{G}(x)$ are the upper and lower membership functions in $G$ respectively. When $\bar{\mu}_{G}(x)=\underline{\mu}_{G}(x)$, the grey set $G$ becomes a fuzzy set. It shows that the condition of fuzziness and dealing flexibly with fuzziness situation is considered by grey theory.

Definition 3. The grey number is defined as a number with uncertain information. For example, the ratings of attributes are described by linguistic variables and numerical intervals are used for description. These numerical intervals include uncertain information. Generally, grey number is written as $\otimes G$

$$
\otimes G=\left.G\right|_{\underline{\mu}} ^{\bar{\mu}} .
$$

Definition 4. Only the lower limit of $\otimes G$ could be estimated and $\otimes G$ is defined as a lower-limit grey number.

$$
\otimes G=[\underline{G}, \infty) .
$$

Definition 5. Only the upper limit of $\otimes G$ could be estimated and $\otimes G$ is defined as a lower-limit grey number.

$$
\otimes G=(-\infty, \bar{G}] .
$$

Definition 6. The lower and upper limits of $\otimes G$ could be estimated and $\otimes G$ is defined as an interval grey number.

$$
\otimes G=[\underline{G}, \bar{G}] .
$$

Definition 7. Grey number operation is defined on sets of intervals, rather than real numbers. The modern development of interval operation began by Moore (1966).

$$
\otimes G_{1}+\otimes G_{2}=\left[\underline{G}_{1}+\underline{G}_{2}, \bar{G}_{1}+\bar{G}_{2}\right],
$$




$$
\begin{aligned}
\otimes G_{1}-\otimes G_{2}= & {\left[\underline{G}_{1}-\bar{G}_{2}, \bar{G}_{1}-\bar{G}_{2}\right], } \\
\otimes G_{1} \times \otimes G_{2}= & {\left[\min \left(\underline{G}_{1} \underline{G}_{2}, \underline{G}_{1} \bar{G}_{2}, \bar{G}_{1} \bar{G}_{2}, \bar{G}_{1} \underline{G}_{2}\right)\right.} \\
& \left.\max \left(\underline{G}_{1} \underline{G}_{2}, \underline{G}_{1} \bar{G}_{2}, \bar{G}_{1} \bar{G}_{2}, \bar{G}_{1} \underline{G}_{2}\right)\right] \\
\otimes G_{1} \div \otimes G_{2}= & {\left[\underline{G}_{1}, \bar{G}_{1}\right] \times\left[\frac{1}{G_{2}}, \frac{1}{\bar{G}_{2}}\right] . }
\end{aligned}
$$

Definition 8. The length of grey number $G$ is defined as

$$
L(\otimes G)=[\bar{G}-\underline{G}] .
$$

Definition 9. The $n$th root of grey number $\otimes G$ is defined as

$$
(\otimes G)^{\frac{1}{n}}=\left[(\underline{G})^{\frac{1}{n}},\left(\overline{G)^{\frac{1}{n}}}\right] .\right.
$$

Definition 10. For two grey numbers $\otimes G_{1}=\left[\underline{G}_{1}, \bar{G}_{1}\right]$ and $\otimes G_{2}=\left[\underline{G}_{2}, \bar{G}_{2}\right]$ the possibility degree of $\otimes G_{1} \leqslant \otimes G_{2}$ could be expressed as follows

$$
P\left\{\otimes G_{1} \leqslant \otimes G_{2}\right\}=\frac{\max \left(0, L^{*}-\max \left(0, \bar{G}_{1}-\underline{G}_{2}\right)\right)}{L^{*}},
$$

where $L^{*}=L\left(\otimes G_{1}\right)+L\left(\otimes G_{2}\right)$.

For the position relationship between $\otimes G_{1}$ and $\otimes G_{2}$, four possible cases exist on the real number axis which are determined as follows:

(1) If $\underline{G}_{1}=\underline{G}_{2}$ and $\bar{G}_{1}=\bar{G}_{2}$, then $\otimes G_{1}$ is equal to $\otimes G_{2}$, denoted as $\otimes G_{1}=\otimes G_{2}$ Then $P\left\{\otimes G_{1} \leqslant \otimes G_{2}\right\}=0.5$.

(2) If $\underline{G}_{2}>\bar{G}_{1}$, then $\otimes G_{2}$ is larger than $\otimes G_{1}$, denoted as $\otimes G_{2}>\otimes G_{1}$. Then $P\left\{\otimes G_{1} \leqslant \otimes G_{2}\right\}=1$.

(3) If $\bar{G}_{2}<\underline{G}_{1}$, we say that $\otimes G_{2}$ is smaller than $\otimes G_{1}$, denoted as $\otimes G_{2}<\otimes G_{1}$. Then $P\left\{\otimes G_{1} \leqslant \otimes G_{2}\right\}=0$.

(4) If there is an intercrossing part in them, when $P\left\{\otimes G_{1} \leqslant \otimes G_{2}\right\}>0.5, \otimes G_{2}$ is larger than $\otimes G_{1}$, denoted as $\otimes G_{2}>\otimes G_{1}$. When $P\left\{\otimes G_{1} \leqslant \otimes G_{2}\right\}<0.5, \otimes G_{2}$ is smaller than $\otimes G_{1}$, denoted as $\otimes G_{2}<\otimes G_{1}$.

\section{Grey TOPSIS}

Grey theory is applied for solving different problems in Economics and management. There are a lot of developed MCDM methods by applying instance TOPSIS grey (Zavadskas et al., 2010a, 2010b; Lin et al., 2008; Chen and Tzeng, 2004; Gu and Song, 2009), SAW grey (Zavadskas et al., 2010a), COPRAS grey (Zavadskas et al., 2009, 2008, 2010b), ARAS grey (Turskis and Zavadskas, 2010), VIKOR (Kuo and Liang, 2011; 
Gauri and Chakraborty, 2010) and ELECTRE (Ozcan et al., 2011). A new approach based on a grey possibility degree and TOPSIS is proposed for ordering the preference of action plans in BSC. This method is very suitable for solving the group decision-making problems in an uncertain environment. Assume that $A=\left\{A_{1}, A_{2}, \ldots, A_{m}\right\}$ is a set of $\mathrm{m}$ possible action plans for a specific strategy and $Q=\left\{Q_{1}, Q_{2}, \ldots, Q_{n}\right\}$ is a set of $\mathrm{n}$ attributes that should be considered in ordering these action plans. $w=\left\{w_{1}, w_{2}, \ldots, w_{n}\right\}$ is the vector of attribute weights. In this paper, the attribute weights and ratings of alternatives are considered as linguistic variables. Here, these linguistic variables are expressed in grey numbers by scales which are accepted by DMs. The process of ordering the preference of action plans is summarized as follow:

Step 1. Form a committee of decision makers and identify the attribute weights of alternatives. Assume that the decision group has $K$ person, the weight of attribute $Q_{j}$ is calculated as

$$
\otimes w_{j}=\left(\otimes w_{1 j}^{p_{1}} \cdot \otimes w_{2 j}^{p_{2}} \cdots \otimes w_{l j}^{p_{l}}\right)^{\frac{1}{\sum p_{l}}}
$$

where $\otimes w_{l j}^{p_{k}}(j=1,2, \ldots, n)$ is the weight which $l$ th $\mathrm{DM}, l=1,2, \ldots, K$, assign to the attribute $Q_{j}$, and is described by grey number $\otimes w_{l j}=\left[\underline{w}_{l j}, \bar{w}_{l j}\right]$. The vector of DMs' judgment weights is $P_{l}(l=1,2, \ldots, K)$ that should be considered in decision making process, determined by the importance of his/her opinion in decision making.

Step 2. Use linguistic variables for the ratings to make an attribute rating value. Then, the rating value is calculated as

$$
\otimes G_{i j}=\left(\otimes G_{1 i j}^{p_{1}} \cdot \otimes G_{2 i j}^{p_{2}} \cdots \otimes G_{l i j}^{p_{l}}\right)^{\frac{1}{\sum_{l}}}
$$

where $G_{l i j}(i=1,2, \ldots, m ; j=1,2, \ldots, n)$ is the attribute rating value of $l$ th DM and is described by the grey number $\otimes G_{l i j}=\left[\underline{G}_{l i j}, \bar{G}_{l i j}\right]$.

Step 3. Establish the grey decision matrix

$$
D=\left[\begin{array}{cccc}
\otimes G_{11} & \otimes G_{12} & \cdots & \otimes G_{1 n} \\
\otimes G_{21} & \otimes G_{22} & \cdots & \otimes G_{2 n} \\
\vdots & \vdots & \ddots & \vdots \\
\otimes G_{m 1} & \otimes G_{m 2} & \cdots & \otimes G_{m n}
\end{array}\right],
$$

where $\otimes G_{i j}$ are linguistic variables based on the grey numbers.

Step 4. Normalize the grey decision matrix

$$
D=\left[\begin{array}{cccc}
\otimes G_{11}^{*} & \otimes G_{12}^{*} & \cdots & \otimes G_{1 n}^{*} \\
\otimes G_{21}^{*} & \otimes G_{22}^{*} & \cdots & \otimes G_{2 n}^{*} \\
\vdots & \vdots & \ddots & \vdots \\
\otimes G_{m 1}^{*} & \otimes G_{m 2}^{*} & \cdots & \otimes G_{m n}^{*}
\end{array}\right]
$$


where for a benefit attribute, $\otimes G_{i j}^{*}$ is expressed as

$$
\otimes G_{i j}^{*}=\left[\frac{\underline{G}_{i j}}{G_{j}^{\max }}, \frac{\underline{G}_{i j}}{G_{j}^{\max }}\right],
$$

where $G_{j}^{\max }=\max _{1 \leqslant i \leqslant m}\left\{\bar{G}_{i j}\right\}$.

And for a cost attribute, $\otimes G_{i j}^{*}$ is expressed as

$$
\otimes G_{i j}^{*}=\left[\frac{G_{j}^{\min }}{\bar{G}_{i j}}, \frac{G_{j}^{\min }}{\underline{G}_{i j}}\right],
$$

where $G_{j}^{\min }=\min _{1 \leqslant i \leqslant m}\left\{\underline{G}_{i j}\right\}$.

The aforementioned normalization method is to ascertain that the ranges of the normalized grey number belong to $[0,1]$.

Step 5. Establish the weighted normalized grey decision matrix. Considering the different importance of each attribute, the weighted normalized grey decision matrix is established as

$$
D^{\star}=\left[\begin{array}{cccc}
\otimes V_{11} & \otimes V_{12} & \cdots & \otimes V_{1 n} \\
\otimes V_{21} & \otimes V_{22} & \cdots & \otimes V_{2 n} \\
\vdots & \vdots & \ddots & \vdots \\
\otimes V_{m 1} & \otimes V_{m 2} & \cdots & \otimes V_{m n}
\end{array}\right],
$$

where $\otimes V_{i j}=\otimes G_{i j}^{*} \times \otimes w_{j}$.

Step 6. Make the ideal alternative as a referential alternative. For $\mathrm{m}$ possible action plans set $A=\left\{A_{1}, A_{2}, \ldots, A_{m}\right\}$, the ideal referential action plan $A^{\max }=$ $\left\{\otimes G_{1}^{\max }, \otimes G_{2}^{\max }, \ldots, \otimes G_{n}^{\max }\right\}$ is obtained by

$$
\begin{aligned}
A^{\max }= & \left\{\left[\max _{1 \leqslant i \leqslant m} \underline{V}_{i 1}, \max _{1 \leqslant i \leqslant m} \bar{V}_{i 1}\right],\left[\max _{1 \leqslant i \leqslant m} \underline{V}_{i 2}, \max _{1 \leqslant i \leqslant m} \bar{V}_{i 2}\right], \ldots,\right. \\
& {\left.\left[\max _{1 \leqslant i \leqslant m} \underline{V}_{i n}, \max _{1 \leqslant i \leqslant m} \bar{V}_{i n}\right]\right\} . }
\end{aligned}
$$

Step 7. Calculate the grey possibility degree between compared action plans set $A=\left\{A_{1}, A_{2}, \ldots, A_{m}\right\}$ and ideal referential action plan $S^{\max }$.

$$
P\left\{A_{i} \leqslant A^{\max }\right\}=\frac{1}{n} \sum_{j=1}^{n} P\left\{\otimes V_{i j} \leqslant \otimes G_{j}^{\max }\right\} .
$$

Step 8 . Classify the order of action plans. When $P\left\{A_{i} \leqslant A_{\max }\right\}$ is smaller, the ranking order of $A_{i}$ is better. Otherwise, the ranking order is worse. 
Table 1

The scale of attribute weights $\otimes w$.

\begin{tabular}{ll}
\hline Scale & $\otimes w$ \\
\hline Very Low (VL) & {$[0.1,0.2]$} \\
Low (L) & {$[0,2,0.3]$} \\
Medium Low (ML) & {$[0.3,0.4]$} \\
Medium (M) & {$[0.4,0.5]$} \\
Medium High (MH) & {$[0.5,0.6]$} \\
High (H) & {$[0.6,0.7]$} \\
Very High (VH) & {$[0.7,0.8]$} \\
\hline
\end{tabular}

Table 2

The scale of attribute ratings $\otimes G$.

\begin{tabular}{|c|c|c|}
\hline \multicolumn{2}{|l|}{ Scale } & \multirow{2}{*}{$\begin{array}{l}\text { Grey number } \\
\otimes G\end{array}$} \\
\hline Acceptance \& effectiveness & Cost \& time delay & \\
\hline Very Poor (VP) & Very Height (VH) & {$[1,2]$} \\
\hline Poor (P) & Height $(\mathrm{H})$ & {$[2,3]$} \\
\hline Medium Poor (MP) & Medium Height $(\mathrm{MH})$ & {$[3,4]$} \\
\hline Fair (F) & Medium (M) & {$[4,5]$} \\
\hline Medium Good (MG) & Medium Low (ML) & {$[5,6]$} \\
\hline Good $(\mathrm{G})$ & Low (L) & {$[6,7]$} \\
\hline Very Good (VG) & Very Low (VL) & {$[7,8]$} \\
\hline
\end{tabular}

According to the above procedure, the ranking order of action plans could be determined and considering the organization budget and resources a group of best action plans are selected.

\section{Numerical Example}

OPCO is a Customized Automotive Production Company. One of the main strategies that have been considered for OPCO is "development and extension of market share" and the BSC and strategy map defined for this strategy is shown in Fig. 5.

There are sixteen action plans $A_{i}(i=1,2, \ldots, 16)$ selected as alternatives against four attributes $Q_{j}(j=1,2,3,4)$. The four attributes are Acceptance, Effectiveness, estimated costs, Time delay. $Q_{1}$ and $Q_{2}$ are benefit attributes where the greater value is better. $Q_{3}$ and $Q_{4}$ is a cost attribute where the smaller values are better. The scales used in decision making process are shown in Tables 1 and 2. The calculation procedure is as follows:

Step 1. The weight of attributes $Q_{1}, Q_{2}, Q_{3}$ and $Q_{4}$ were made. A committee of four DMs, $D_{1}, D_{2}, D_{3}$ and $D_{4}$ were formed to express their preferences. According to Eq. (13), the values of attribute weights from four MDs were obtained and the results are shown in Table 3.

Step 2. Attribute rating values for sixteen action plans were established. According to Eq. (14), the results of attribute rating values are shown in Table 4. 


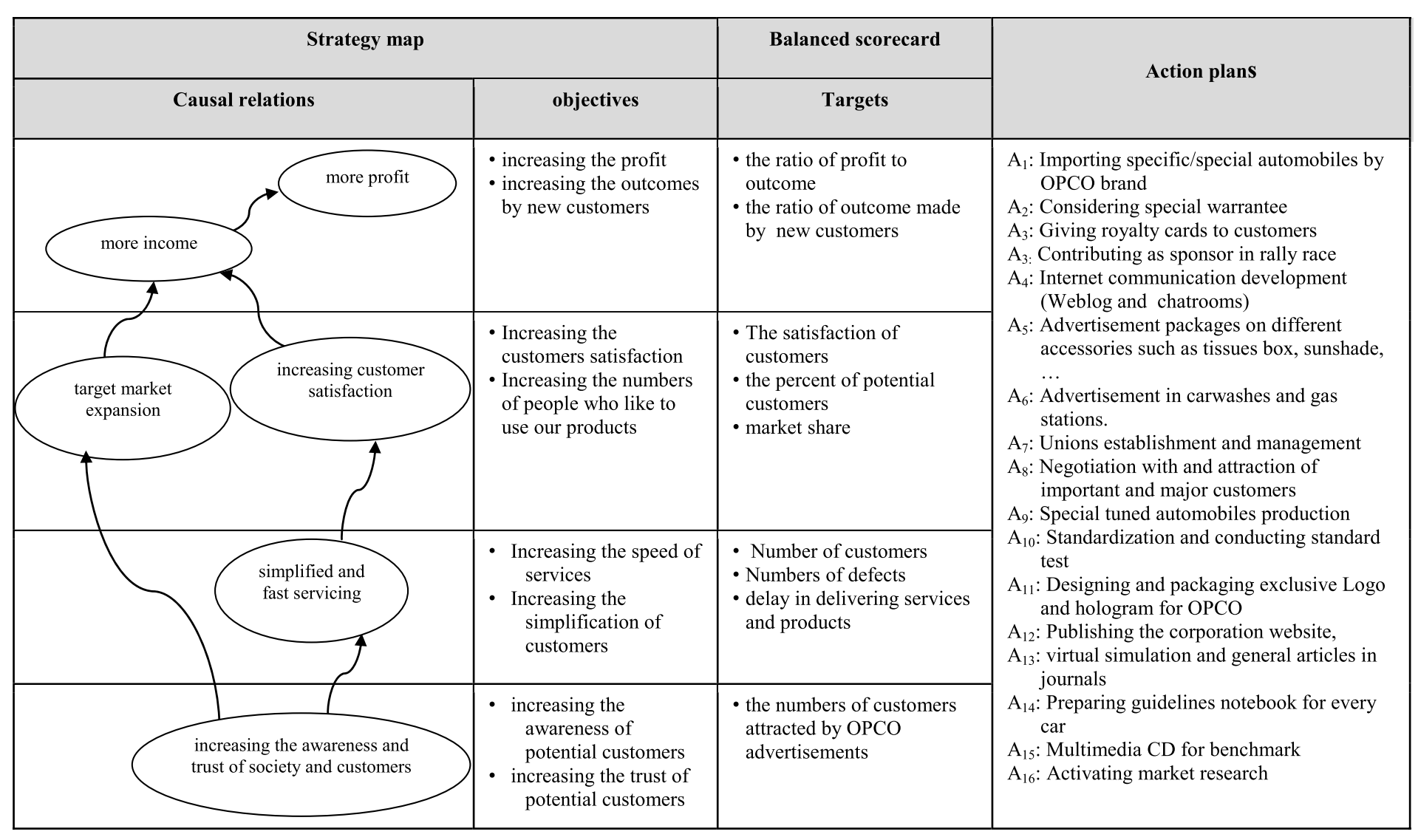

Fig. 5. The balanced scorecard for OPCO stategy. 
Table 3

Attribute weights for sixteen action plans.

\begin{tabular}{llllll}
\hline$Q_{i}$ & $D_{1}$ & $D_{2}$ & $D_{3}$ & $D_{4}$ & $\otimes W_{j}$ \\
\hline$Q_{1}$ & $\mathrm{~L}$ & $\mathrm{~L}$ & $\mathrm{VL}$ & $\mathrm{VL}$ & {$[0.141,0.245]$} \\
$Q_{2}$ & $\mathrm{H}$ & $\mathrm{VH}$ & $\mathrm{VH}$ & $\mathrm{H}$ & {$[0.648,0.748]$} \\
$Q_{3}$ & $\mathrm{VH}$ & $\mathrm{H}$ & $\mathrm{H}$ & $\mathrm{H}$ & {$[0.624,0.724]$} \\
$Q_{4}$ & $\mathrm{MH}$ & $\mathrm{M}$ & $\mathrm{MH}$ & $\mathrm{M}$ & {$[0.447,0.548]$} \\
\hline
\end{tabular}

Table 4

Attribute rating values for suppliers.

\begin{tabular}{|c|c|c|c|c|c|c|c|c|c|c|c|c|c|}
\hline$Q_{i}$ & $A_{i}$ & $D_{1}$ & $D_{2}$ & $D_{3}$ & $D_{4}$ & $\otimes G_{i j}$ & $Q_{i}$ & $A_{i}$ & $D_{1}$ & $D_{2}$ & $D_{3}$ & $D_{4}$ & $\otimes G_{i j}$ \\
\hline \multirow[t]{16}{*}{$Q_{1}$} & $A_{1}$ & $\mathrm{VP}$ & $\mathrm{P}$ & $\mathrm{VP}$ & $\mathrm{P}$ & {$[1.41,2.45]$} & \multirow[t]{16}{*}{$Q_{3}$} & $A_{1}$ & M & $\mathrm{MH}$ & $\mathrm{MH}$ & M & {$[3.46,4.47]$} \\
\hline & $A_{2}$ & $\mathrm{~F}$ & M & $\mathrm{F}$ & MG & {$[4.23,5.23]$} & & $A_{2}$ & M & ML & $\mathrm{L}$ & $\mathrm{L}$ & {$[5.18,6.19]$} \\
\hline & $A_{3}$ & $\mathrm{P}$ & $\mathrm{P}$ & $\mathrm{P}$ & $\mathrm{P}$ & {$[2.00,3.00]$} & & $A_{3}$ & $\mathrm{~L}$ & VL & VL & $\mathrm{VL}$ & {$[6.74,7.74]$} \\
\hline & $A_{4}$ & $\mathrm{~F}$ & MG & $\mathrm{F}$ & $\mathrm{F}$ & {$[4.23,5.23]$} & & $A_{4}$ & $\mathrm{H}$ & $\mathrm{H}$ & $\mathrm{H}$ & $\mathrm{VH}$ & {$[1.68,2.71]$} \\
\hline & $A_{5}$ & $\mathrm{P}$ & MP & $\mathrm{P}$ & $\mathrm{P}$ & {$[2.21,3.22]$} & & $A_{5}$ & VL & VL & $\mathrm{L}$ & ML & {$[6.19,7.20]$} \\
\hline & $A_{6}$ & $\mathrm{~F}$ & MG & G & $\mathrm{F}$ & {$[4.68,5.69]$} & & $A_{6}$ & ML & ML & $\mathrm{L}$ & $\mathrm{H}$ & {$[4.16,5.24]$} \\
\hline & $A_{7}$ & G & G & G & MG & {$[5.73,6.74]$} & & $A_{7}$ & $\mathrm{~L}$ & M & ML & $\mathrm{L}$ & {$[5.18,6.19]$} \\
\hline & $A_{8}$ & VG & VG & $\mathrm{G}$ & VG & {$[6.74,7.74]$} & & $A_{8}$ & ML & ML & $\mathrm{L}$ & VL & {$[5.69,6.70]$} \\
\hline & $A_{9}$ & G & G & G & G & {$[6.00,7.00]$} & & $A_{9}$ & $\mathrm{~L}$ & $\mathrm{~L}$ & $\mathrm{~L}$ & $\mathrm{~L}$ & {$[6.00,7.00]$} \\
\hline & $A_{10}$ & $\mathrm{P}$ & $\mathrm{P}$ & $\mathrm{VP}$ & MP & {$[1.86,2.91]$} & & $A_{10}$ & $\mathrm{VH}$ & $\mathrm{H}$ & $\mathrm{H}$ & $\mathrm{H}$ & {$[1.68,2.71]$} \\
\hline & $A_{11}$ & $\mathrm{G}$ & $\mathrm{G}$ & MG & G & {$[5.73,6.74]$} & & $A_{11}$ & ML & $\mathrm{L}$ & ML & ML & {$[5.23,6.24]$} \\
\hline & $A_{12}$ & VG & G & VG & G & {$[6.48,7.48]$} & & $A_{12}$ & VL & VL & VL & $\mathrm{L}$ & {$[6.74,7.74]$} \\
\hline & $A_{13}$ & MG & G & G & MG & {$[5.48,6.48]$} & & $A_{13}$ & VL & $\mathrm{L}$ & VL & $\mathrm{L}$ & {$[6.48,7.48]$} \\
\hline & $A_{14}$ & G & G & VG & VG & {$[6.48,7.48]$} & & $A_{14}$ & ML & ML & ML & $\mathrm{L}$ & {$[5.23,6.24]$} \\
\hline & $A_{15}$ & $\mathrm{~F}$ & $\mathrm{P}$ & MP & MP & {$[2.91,3.94]$} & & $A_{15}$ & $\mathrm{~L}$ & $\mathrm{~L}$ & $\mathrm{~L}$ & VL & {$[6.24,7.24]$} \\
\hline & $A_{16}$ & MG & G & G & VG & {$[6.48,7.48]$} & & $A_{16}$ & VL & $\mathrm{L}$ & $\mathrm{L}$ & $\mathrm{L}$ & {$[6.24,7.24]$} \\
\hline \multirow[t]{16}{*}{$Q_{2}$} & $A_{1}$ & MG & G & G & G & {$[5.73,6.74]$} & \multirow[t]{16}{*}{$Q_{4}$} & $A_{1}$ & $\mathrm{MH}$ & $\mathrm{H}$ & $\Pi$ & MH & {$[2.4$} \\
\hline & $A_{2}$ & MG & $\mathrm{F}$ & G & $\mathrm{F}$ & {$[4.68,5.69]$} & & $A_{2}$ & $\mathrm{~L}$ & $\mathrm{~L}$ & $\mathrm{~L}$ & $\mathrm{VL}$ & {$[6.24,7.24]$} \\
\hline & $A_{3}$ & $\mathrm{P}$ & $\mathrm{P}$ & $\mathrm{P}$ & VP & {$[1.68,2.71]$} & & $A_{3}$ & $\mathrm{VH}$ & $\mathrm{VH}$ & $\mathrm{VH}$ & $\mathrm{VH}$ & {$[1.00,2.00]$} \\
\hline & $A_{4}$ & MP & MP & $\mathrm{P}$ & $\mathrm{P}$ & {$[2.45,3.46]$} & & $A_{4}$ & M & $\mathrm{MH}$ & $\mathrm{H}$ & $\mathrm{H}$ & {$[2.63,3.66]$} \\
\hline & $A_{5}$ & MP & $\mathrm{P}$ & $\mathrm{P}$ & VP & {$[1.86,2.91]$} & & $A_{5}$ & M & M & M & MH & {$[3.72,4.73]$} \\
\hline & $A_{6}$ & G & G & G & G & {$[6.00,7.00]$} & & $A_{6}$ & VL & VL & $\mathrm{L}$ & $\mathrm{L}$ & {$[6.48,7.48]$} \\
\hline & $A_{7}$ & G & VG & MG & VG & {$[6.19,7.20]$} & & $A_{7}$ & $\mathrm{~L}$ & $\mathrm{~L}$ & ML & ML & {$[5.48,6.48]$} \\
\hline & $A_{8}$ & G & G & VG & MG & {$[5.69,6.96]$} & & $A_{8}$ & ML & $\mathrm{L}$ & $\mathrm{L}$ & $\mathrm{VL}$ & {$[5.96,6.96]$} \\
\hline & $A_{9}$ & $\mathrm{G}$ & G & VG & VG & {$[6.48,7.48]$} & & $A_{9}$ & $\mathrm{MH}$ & $\mathrm{H}$ & M & $\mathrm{H}$ & {$[2.63,3.66]$} \\
\hline & $A_{10}$ & G & G & G & MG & {$[5.73,6.74]$} & & $A_{10}$ & M & ML & MH & $\mathrm{L}$ & {$[4.36,5.38]$} \\
\hline & $A_{11}$ & $\mathrm{~F}$ & MP & $\mathrm{P}$ & $\mathrm{F}$ & {$[3.13,4.16]$} & & $A_{11}$ & ML & VL & ML & VL & {$[5.92,6.93]$} \\
\hline & $A_{12}$ & G & MG & MG & VG & {$[5.69,6.70]$} & & $A_{12}$ & VL & VL & VL & VL & {$[7.00,8.00]$} \\
\hline & $A_{13}$ & $\mathrm{P}$ & $\mathrm{P}$ & $\mathrm{P}$ & MP & {$[2.21,3.22]$} & & $A_{13}$ & $\mathrm{VH}$ & $\mathrm{H}$ & $\mathrm{H}$ & $\mathrm{H}$ & {$[1.68,2.71]$} \\
\hline & $A_{14}$ & VG & VG & VG & VG & {$[7.00,8.00]$} & & $A_{14}$ & $\mathrm{~L}$ & $\mathrm{~L}$ & VL & ML & {$[5.96,6.96]$} \\
\hline & $A_{15}$ & $\mathrm{P}$ & $\mathrm{P}$ & MP & MP & {$[2.45,3.46]$} & & $A_{15}$ & $\mathrm{VH}$ & $\mathrm{H}$ & $\mathrm{H}$ & MH & {$[1.86,2.91]$} \\
\hline & $A_{16}$ & VG & G & MG & MG & {$[5.69,6.70]$} & & $A_{16}$ & VL & $\mathrm{L}$ & ML & $\mathrm{L}$ & {$[5.96,6.96]$} \\
\hline
\end{tabular}

Step 3. The grey decision matrix was founded. According to Eq. (15), the grey decision matrix of action plans was obtained.

Step 4. The grey normalized decision matrix was determined. According to grey normalized decision matrix Eqs. (16), (17) and (18) the grey normalized decision table is shown in Table 5. 
Table 5

Grey normalized decision table.

\begin{tabular}{lllll}
\hline$A_{i}$ & $Q_{1}$ & $Q_{2}$ & $Q_{3}$ & $Q_{4}$ \\
\hline$A_{1}$ & {$[0.18,0.32]$} & {$[0.72,0.84]$} & {$[0.38,0.49]$} & {$[0.29,0.41]$} \\
$A_{2}$ & {$[0.59,0.71]$} & {$[0.27,0.32]$} & {$[0.14,0.16]$} \\
$A_{3}$ & {$[0.55,0.68]$} & {$[0.21,0.34]$} & {$[0.22,0.25]$} & {$[0.50,1.00]$} \\
$A_{4}$ & {$[0.26,0.39]$} & {$[0.31,0.43]$} & {$[0.62,1.00]$} & {$[0.27,0.38]$} \\
$A_{5}$ & {$[0.55,0.68]$} & {$[0.23,0.36]$} & {$[0.23,0.27]$} & {$[0.21,0.27]$} \\
$A_{6}$ & {$[0.29,0.42]$} & {$[0.75,0.88]$} & {$[0.32,0.40]$} & {$[0.13,0.15]$} \\
$A_{7}$ & {$[0.60,0.74]$} & {$[0.77,0.90]$} & {$[0.27,0.32]$} & {$[0.15,0.18]$} \\
$A_{8}$ & {$[0.74,0.87]$} & {$[0.75,0.87]$} & {$[0.25,0.30]$} & {$[0.14,0.17]$} \\
$A_{9}$ & {$[0.78,0.90]$} & {$[0.81,0.94]$} & {$[0.24,0.28]$} & {$[0.27,0.38]$} \\
$A_{10}$ & {$[0.24,0.38]$} & {$[0.72,0.84]$} & {$[0.62,1.00]$} & {$[0.19,0.23]$} \\
$A_{11}$ & {$[0.24,0.38]$} & {$[0.39,0.52]$} & {$[0.27,0.32]$} & {$[0.14,0.17]$} \\
$A_{12}$ & {$[0.74,0.87]$} & {$[0.71,0.84]$} & {$[0.22,0.25]$} & {$[0.13,0.14]$} \\
$A_{13}$ & {$[0.84,0.97]$} & {$[0.28,0.40]$} & {$[0.22,0.26]$} & {$[0.37,0.60]$} \\
$A_{14}$ & {$[0.71,0.84]$} & {$[0.88,1.00]$} & {$[0.27,0.32]$} & {$[0.14,0.17]$} \\
$A_{15}$ & {$[0.84,0.97]$} & {$[0.31,0.43]$} & {$[0.23,0.27]$} & {$[0.34,0.54]$} \\
$A_{16}$ & {$[0.38,0.51]$} & {$[0.71,0.84]$} & {$[0.23,0.27]$} & {$[0.14,0.17]$} \\
\hline
\end{tabular}

Table 6

Grey weighted normalized decision table

\begin{tabular}{lllll}
\hline$A_{i}$ & $Q_{1}$ & $Q_{2}$ & $Q_{3}$ & $Q_{4}$ \\
\hline$A_{1}$ & {$[0.03,0.08]$} & {$[0.47,0.63]$} & {$[0.24,0.35]$} & {$[0.13,0.22]$} \\
$A_{2}$ & {$[0.08,0.17]$} & {$[0.38,0.53]$} & {$[0.17,0.23]$} & {$[0.06,0.09]$} \\
$A_{3}$ & {$[0.04,0.10]$} & {$[0.14,0.25]$} & {$[0.14,0.18]$} & {$[0.22,0.55]$} \\
$A_{4}$ & {$[0.08,0.17]$} & {$[0.20,0.32]$} & {$[0.39,0.72]$} & {$[0.12,0.21]$} \\
$A_{5}$ & {$[0.04,0.10]$} & {$[0.15,0.27]$} & {$[0.14,0.20]$} & {$[0.09,0.15]$} \\
$A_{6}$ & {$[0.08,0.18]$} & {$[0.49,0.66]$} & {$[0.20,0.29]$} & {$[0.06,0.08]$} \\
$A_{7}$ & {$[0.10,0.21]$} & {$[0.50,0.67]$} & {$[0.17,0.23]$} & {$[0.07,0.10]$} \\
$A_{8}$ & {$[0.12,0.25]$} & {$[0.49,0.65]$} & {$[0.16,0.22]$} & {$[0.06,0.09]$} \\
$A_{9}$ & {$[0.11,0.22]$} & {$[0.52,0.70]$} & {$[0.15,0.20]$} & {$[0.12,0.21]$} \\
$A_{10}$ & {$[0.03,0.09]$} & {$[0.47,0.63]$} & {$[0.39,0.72]$} & {$[0.08,0.13]$} \\
$A_{11}$ & {$[0.10,0.21]$} & {$[0.25,0.39]$} & {$[0.17,0.23]$} & {$[0.06,0.09]$} \\
$A_{12}$ & {$[0.12,0.24]$} & {$[0.46,0.63]$} & {$[0.14,0.18]$} & {$[0.06,0.08]$} \\
$A_{13}$ & {$[0.10,0.21]$} & {$[0.18,0.30]$} & {$[0.14,0.19]$} & {$[0.17,0.33]$} \\
$A_{14}$ & {$[0.12,0.24]$} & {$[0.57,0.75]$} & {$[0.17,0.23]$} & {$[0.06,0.09]$} \\
$A_{15}$ & {$[0.05,0.12]$} & {$[0.20,0.32]$} & {$[0.14,0.20]$} & {$[0.15,0.30]$} \\
$A_{16}$ & {$[0.12,0.24]$} & {$[0.46,0.63]$} & {$[0.14,0.20]$} & {$[0.06,0.09]$} \\
\hline
\end{tabular}

Step 5. The grey weighted normalized decision matrix was established. According to the grey weighted normalized decision matrix Eq. (19), the grey weighted normalized decision table is shown in Table 6.

Step 6. The ideal action plan $A_{\max }$ a referential alternative was recognized. According to Eq. (20), the ideal action plan $A_{\max }$ is:

$$
A^{\max }=\{[0.12,0.25],[0.57,0.75],[0.39,0.72],[0.22,0.55]\} .
$$


Table 7

The grey possibility degree between the action plans and the ideal referential action plan $A_{\max }$.

\begin{tabular}{llllllll}
\hline$A_{i}$ & $P\left(A_{i}<A^{\max }\right)$ & $A_{i}$ & $P\left(A_{i}<A^{\max }\right)$ & $A_{i}$ & $P\left(A_{i}<A^{\max }\right)$ & $A_{i}$ & $P\left(A_{i}<A^{\max }\right)$ \\
\hline$A_{1}$ & 0.965 & $A_{5}$ & 1 & $A_{9}$ & 0.806 & $A_{13}$ & 0.850 \\
$A_{2}$ & 0.943 & $A_{6}$ & 0.871 & $A_{10}$ & 0.831 & $A_{14}$ & 0.755 \\
$A_{3}$ & 0.875 & $A_{7}$ & 0.835 & $A_{11}$ & 0.906 & $A_{15}$ & 0.833 \\
$A_{4}$ & 0.818 & $A_{8}$ & 0.816 & $A_{12}$ & 0.837 & $A_{16}$ & 0.837 \\
\hline
\end{tabular}

Step 7. The grey possibility degree between the compared action plans $A_{i}(i=$ $1,2, \ldots, 16)$ and the ideal referential action plan $A_{\max }$ was calculated. According to Eq. (21), the results of the grey possibility degree are shown in Table 7.

Step 8 . The order of sixteen action plans $A_{i}(i=1,2, \ldots, 16)$ was ranked. According to Step 7, the result of preference order is:

$$
\begin{aligned}
A_{14} & >\circ A_{9}>\circ A_{8}>\circ A_{4}>\circ A_{10}>\circ A_{15}>\circ A_{7}>\circ A_{12}, A_{16}>\circ A_{13}>\circ A_{6}>\circ A_{3}>\circ A_{11} \\
& >\circ A_{2}>\circ A_{1}>\circ A_{5}
\end{aligned}
$$

\section{Conclusion}

Nowadays, ambiguity, uncertainty and incomplete information are the main aspects of decision making process. In decision making, managers are faced with different criteria that should be considered in decision making process. Using theories like fuzzy sets and grey theory through multi criteria decision making techniques can help managers to solve these problems. In this paper, a procedure based on TOPSIS and Grey theory is suggested for ordering the preference of action plans in a group decision making process. Grey numbers is used for deriving the judgments of DMs about the attribute weights and determining the performance of each action plans in ordering the preference of action plans.

\section{References}

Alizadeh, A., Dabbaghi, A., Malek, A.A. (2008). Proposing a model for evaluating corporate vision statement using Grey systems theory, Tehran. In: Third International Strategic Management Conference, pp. 12-22.

Cao, L.W., Yun-huan, C., Zhang, J., Zhou, X., Lian, C.X. (2006). Application of grey situation decision-making theory in site selection of a waste sanitary landfill. Journal of China University of Mining and Technology, 16(4), 393-398.

Chen, M.F, Tzeng, G.H. (2004). Combining grey relation and TOPSIS concepts for selecting an expatriate host country. Mathematical and Computer Modeling, 40(13), 1473-1490.

David, F.R. (2009). Concepts of Strategic Management, 12th ed., Prentice-Hall, New Jersey.

Deng, J. (1989). Introduction to grey system theory. The Journal of Grey System, 1, 1-24.

Dong, G., Yamaguchi, D., Nagai, M. (2006). A grey-based decision - making approach to the supplier selection problem. Mathematical and Computer Modeling, 46, 573-581.

Gauri, S.K, Chakraborty, S. (2010). A study on the performance of some multi-response optimisation methods for WEDM processes. International Journal of Advanced Manufacturing Technology, 49(1-4), 155-166. 
Gu, H., Song, B.F. (2009). Study on effectiveness evaluation of weapon systems based on grey relational analysis and TOPSIS. Journal of Systems Engineering and Electronics, 20(1), 106-111.

Kaplan, R.S., Norton, D.P. (1993). Putting the balanced scorecard to work. Harvard Business Review, September/October, 134-142.

Kaplan, R.S., Norton, D.P. (1996a). Strategic learning \& the balanced scorecard. Strategy \& Leadership, 24(5), $18-24$.

Kaplan, R.S., Norton, D.P. (1996b). Linking the balanced scorecard to strategy. California Management Review, 39(1), 53-79.

Kaplan, R.S., Norton, D.P. (2001a). Transforming the balanced scorecard from performance measurement to strategic management (part 1). Accounting Horizons, 15(1), 87-104.

Kaplan, R.S., Norton, D.P. (2001b). Transforming the balanced scorecard from performance measurement to strategic management (part 2). Accounting Horizons, 15(2), 147-160.

Kaplan, R.S., Norton, D.P. (2004a). How strategy maps frame an organization's objectives. Financial Executive, 20(2), 40-45.

Kaplan, R.S., Norton, D.P. (2004b). Plotting success with "strategy maps". Optimize, February, 61-65.

Kaplan, R.S., Norton, D.P. (2007a). Alignment: Using the Balanced Scorecard to Create Corporate Synergies. Harvard Business School Press, Massachusetts.

Kaplan, R.S., Norton, D.P. (2007b). Strategy Map: Converting Intangible Assets into Tangible Outcomes. Harvard Business School Press, Massachusetts.

Kaplan, R.S., Norton, D.P. (2008). Strategy Focused Organization. How Balanced Scorecard Company Thrive in the New Business Environment. Harvard Business School Press, Massachusetts.

Kuo, Y., Yang, T., Huang, G.W. (2008). The use of grey relational analysis in solving multiple attribute decisionmaking problems. Computers \& Industrial Engineering, 55(1), 80-93.

Kuo, M.S., Liang, G.S. (2011). Combining VIKOR with GRA techniques to evaluate service quality of airports under fuzzy environment. Expert Systems with Applications, 38(3), 1304-1312.

Kung, C.Y., Wen, K.L. (2007). Applying grey relational analysis and grey decision-making to evaluate the relationship between company attributes and its financial performance- a case study of venture capital enterprises in Taiwan. Decision Support System, 43(3), 842-852.

Li, G.D., Yamaguchi, D., Nagai, M. (2007). A grey-based decision-making approach to the supplier selection problem. Mathematical and Computer Modelling, 46(3-4), 573-581.

Lin, Y.H., Lee, P.Ch., Chang, T.P., Ting, H.I. (2008). Multi-attribute group decision making model under the condition of uncertain information. Automation in Construction, 17(6), 792-797.

Moore, R.E. (1966). Interval Analysis. Prentice-Hall, London.

Ozcan, T., Celebi, N., Esnaf, S. (2011). Comparative analysis of multi-criteria decision making methodologies and implementation of a warehouse location selection problem. Expert Systems with Applications, 38(8), 9773-9779.

Pearce, J., Robinson, R. 1997. Strategic Management: Formulation, Implementation and Control, 6th edn. Irwin, Chicago.

Turskis, Z., Zavadskas, E.K. (2010). A novel method for multiple criteria analysis: grey additive ratio assessment (ARAS-G) method. Informatica, 21(4), 597-610.

Zavadskas, E.K., Turskis, Z., Tamošaitienè, J., Marina, V. (2008). Multicriteria selection of project managers by applying grey criteria. Technological and Economic Development of Economy, 14(4), 462-477.

Zavadskas, E.K., Kaklauskas, A., Turskis, Z., Tamošaitienè, J. (2009). Multi-attribute decision-making model by applying grey numbers. Informatica, 20(2), 305-320.

Zavadskas, E.K., Vilutienė, T., Z. Turskis, Tamošaitienė, J. (2010a). Contractor selection for construction works by applying SAW-G and TOPSIS grey techniques. Journal of Business Economics and Management, 11(1), $34-55$.

Zavadskas, E.K., Turskis, Z., Tamošaitienė, J. (2010b). Risk assessment of construction projects. Journal of Civil Engineering and Management, 16(1), 33-46.

Zhang, J., W. Desheng, and D.L. Olson (2005). The method of grey related analysis to multiple attribute decision making problems with interval numbers. Mathematical and Computer Modelling, 42(9-10), 991-998. 
M. Sadeghi received BS degree in industrial management at Shiraz Azad University, Shiraz Iran. He received MS degree in management at Shiraz University, Shiraz, Iran. He received PhD degree at Allameh Tabataba'i University, Tehran, Iran. His research experiences include optimization problems, production management and planning problems; He teaches operational research, statistics and its applications in management and decision making theory in Allameh Tabataba'i University.

S.H. Razavi received his BSc in Industrial Engineering at Islamic Azad University, 2005 and his M.A. in Industrial management at Allameh Tabataba'i University, 2007. He has worked as a researcher at institute for Trade Studies and Researches since 2008. He has received his $\mathrm{PhD}$ at the same university, 2012. His research interest spans the fields of Operation research and Decision making methods under uncertainty. He has taught operation research at Allame University since 2009 and he has published some papers in these areas.

N. Saberi received BS degree in math at Shahid Beheshti University, Tehran, Iran. She received MS degree in industrial engineering at Qazvin Azad University, Qazvin, Iran. Her MS thesis was about Gray Theory. She is an instructress of statistical and probability in Eslamshahr Azad University, Tehran, Iran.

\title{
TOPSIS-Pilko metodo taikymas, rikiuojant veiksmų planus pagal prioritetiškumą, kai taikomos subalansuotos veiklos ataskaitos ir strategijų planai
}

\author{
Mohammadreza SADEGHI, Seyed Hossein RAZAVI, Narges SABERI
}

„Strategijos igyvendinimas“ yra neatsiejama strateginio valdymo proceso dalis. Strategijos transformavimas į tipines operacijas ir kasdienines personalo funkcijas turi svarbų vaidmenį, užtikrinant organizacijos sẻkmingą veiklą. Subalansuota įmonès veiklos ataskaita (SIVA) ir strateginis planas padeda įmonès vadovams pilnai iggyvendinti ir stebėti strategijų ịvykdymą, formuojant operatyvines programas pagal priimtas strategijas. Remiantis strategijomis, formuojami veiksmų planai, kurie leidžia pasiekti organizacijos tikslus ir igyvendinti šias strategijas. Dèl resursų trūkumo dažniausiai organizacijos veiksmų planai negali būti iggyvendinti pilnoje apimtyje, todèl vadovams būtina turèti priemonių, kurios padeda atrinkti efektyvesnius veiksmų planus. Šiame straipsnyje TOPSIS-pilko metodo pagrindų siūloma sprendimų paramos metodika, kuri efektyviau padeda i̇monių vadovams atrinkti efektyviausią veiksmų planą. 